\title{
From The Science of Science to Scientometrics : Visualizing the History of Science with HistCite Software
}

\author{
Eugene Garfield \\ Chairman Emeritus, Thomson ISI, \\ 3501 Market Street, Philadelphia PA 19104 (USA) \\ *garfield@codex.cis.upenn.edu
}

Presented at $11^{\text {th }}$ ISSI Itnernational Conference, Madrid, June 25, 2007

\begin{abstract}
While ISSI was founded in 1993, scientometrics and bibliometrics are now at least half a century old. Indeed, the field can be traced to early quantitative studies in the early $20^{\text {th }}$ Century. In the thirties, it evolved to the "science of science." The publication of J. D. Bernal's Social Function of Science in 1939 was a key transition point but the field lay dormant until after World War II, when DJD Price's books Science Since Babylon and Little Science, Big Science were published in1961 and 1963. His role as the "father of scientometrics" is clearly evident by using the HistCite software to visualize his impact as well as the subsequent impact of the journal Scientometrics on the growth of the field. Scientometrics owes its name to V. V. Nalimov, the author of Naukometriya, and to Tibor Braun who adapted the neologism for the journal. The primordial paper on citation indexing by Garfield which appeared in Science 1955 became a bridge between Bernal and Price. The timeline for the evolution of scientometrics is demonstrated by a HistCite tabulation of the ranked citation index of the 100,000 references cited in the 3,000 papers citing Price.
\end{abstract}

Keywords: history of scientometrics; etymology of scientometrics; Derek J.D. Price; V. V. Nalimov; J. D. Bernal; Science of Science; HistCite; algorithmic; historiography; bibliometrics.

\section{Introduction}

When Henk Moed asked me to present a keynote address to this Eleventh International Conference of the International Society for Scientometrics and Informatics (ISSI) I had mixed feelings. I had previously planned to participate by simply describing my current work on algorithmic historiography. The paper I originally submitted was an up-to-date description of the HistCite system (http://www.histcite.com/). Briefly stated, HistCite ${ }^{\mathrm{TM}}$ is a software system which generates chronological maps of bibliographic collections resulting from subject, author, institutional or source journal searches of the ISI Web of Science. ${ }^{\circledR}$ WoS export files are created in which all cited references for each source document are captured. The software generates chronological historiographs highlighting the most-cited works in the retrieved collection. Other listings include rankings by author, journal, institution, or vocabulary. 
But Henk thought that this might be a good chance to provide the current ISSI membership with some personal reflections on the origins of scientometrics, especially as it is now two decades since the first ISSI conference held in Belgium in 1987 and 14 years since ISSI was founded in Berlin. It is noteworthy that the term "scientometrics" itself was not included in the title of the 1987 meeting which was the "First International Conference on Bibliometrics and Theoretical Aspects of Information Retrieval." Twenty years earlier, Alan Pritchard had coined the term bibliometrics in his 1969 paper on statistical bibliography. (Pritchard, 1969).

Most of us have been exposed to the macro history of scientometrics. We recognize names like Derek de Solla Price and V.V. Nalimov and perhaps earlier pioneers in measurement such as Alfred Lotka and George K. Zipf. If you search the Web of Science for the past century, these names will pop up very quickly. But when you search year-by-year you obtain a very different micro-perspective. Today, I would like to recall for you aspects of the micro and macro impact of Derek Price's work, since he is usually considered "the father of Scientometrics." However, this simplistic metaphor for his role in the history of scientometrics, does not adequately reflect the influences of earlier statistically and quantitatively oriented scholars.

In the foreword to the second edition of "Little Science, Big Science," (Merton and Garfield, 1986) Robert K. Merton and I identified Derek as the father of scientometrics because he was perceived, in the western world, to have made the greatest impact on the use of quantitative indicators in formulating science policy. The first edition of the 1963 book was aptly identified as a Citation Classic (Price, 1983) but at the time the book was written, Derek had not even encountered the term scientometrics, which was coined by the Russian mathematician-philosopher-polymath, V. V. Nalimov. "Scientometrics" is the English translation of the title word of Nalimov's classic monograph Naukometriya, ${ }^{\mathrm{i}}$ (Nalimov and Mul'chenko, 1973) which was relatively unknown to western scholars even after it was translated into English. Without access to the internet and limited distribution, it was rarely cited. However, the term became better known once the journal Scientometrics appeared in 1978. Stephen Bensman in a tribute to Tibor Braun recently reminded us how the journal became a bridge between the East and West. (Bensman \& Kraft, in press) To simply mention that Nalimov coined the term scientometrics would be an injustice to his impact as a polymathic author. As with Derek Price I am proud go have been Vassili Nalimov's friend for three decades and to have published four of his books in English. And recently the full texts of those books have been digitized and posted to my website:

http://garfield.library.upenn.edu/nalimov.html . For a more detailed account of Nalimov's role in the history of scientometrics, see Chapter IV of The Citation Culture by Paul Wouters. The full text is posted at http://garfield.library.upenn.edu/wouters/wouters.pdf.

Let me remind you of some historical facts. Price's "Science Since Babylon" (Price 1986) was published six years after my 1955 paper in Science (Garfield, 1955). The first edition of Little Science, Big Science appeared two years later in 1963. The opening page is called a "prologue to a science of science." If Derek was aware of my paper, he did not cite it then. Even in his classic 1965 Networks paper in Science (Price, 1965) he referred to the 1963 Genetics Citation Project and my 1964 Science paper by which time we had made personal contact (Garfield, 1964). But even earlier, in 1962, I had written to J.D. Bernal and Robert K. Merton about the experimental Science Citation Index which resulted from that project. I met Bernal briefly at the International Conference on Scientific Information in Washington in 1958. It was not until 1983, in his Citation Classic commentary (Price, 1983) cited above, that Derek notes that he was "stimulated much by Robert Merton's writings in the sociology of science, by Eugene Garfield's new book on citation indexing, and by rereading Desmond Bernal's books which had prepared my mind for the initial sensitivity that led me to this field in the first place." Of course, Derek could not have read my book at that time because it did not come out until 1979. Perhaps he should have use the term "work" instead. 
In the preface to Volume 3 of my Essays of an Information Scientist, ${ }^{i i}$ (Price DJD, 1980) Derek himself related how we first encountered each other when he was a member of the National Science Foundation's Science Information Council. He reports how I tried to get the NSF to support printing and distribution of the Science Citation Index:

From that day to the present....I have found megavitamins for my intellectual diet on the cutting room floor of ISI's computer room. Bit by bit we have begun to understand how citations work and in the course of this, there has emerged a new sort of statistical sociology of science that has thrown light on many aspects of the authorship, refereeing, and publication of scientific research papers. The Society of Social Studies in Science now has an annual meeting devoted to this new method of understanding science that has grown, almost as an accidental by-product, from the indexing technology developed by the Institute for Scientific Information. Our initial intuitive perceptions have turned out to be correct.(Price, 1980).

The early 4S group ultimately became the Society for the Social Studies in Science (4S) which together with Thomson ISI sponsors the annual Bernal Award. However, the Society's interest in scientometrics has waned considerably in recent years, perhaps in part because of the growth of ISSI which understandably is not as preoccupied with the history and sociology of science per se as is $4 \mathrm{~S}$.

The first co-citational link between Garfield and Price was made in the early sixties by the mathematical statistician, John W. Tukey (Tukey 1962). Between 1955 and 1964 he was the only author who co-cited me and Derek. Keep in mind that Tukey was not a scientometrician. Like myself at the time, he was primarily interested in helping scientists to keep in touch with the literature. He and Joshua Lederberg played a key role, especially through the Weinberg Committee report, in promoting the idea of citation indexes as a new and promising method for information retrieval. No one was then actively talking about citation indexing as a scientometric or science policy tool per se. Alan Pritchard's paper on "Statistical Bibliography," mentioned earlier, did not appear until 1969 but was not cited for science policy purposes.

Another early science policy scholar was the Yugoslav Stevan Dedijer. (Dedijer,1962) Like Tukey he was aware of the work by Derek Price but in those early years there were only vague references to the use of bibliometric data for science policy purposes. Rather, the term "science of science" was used by Price, (Price 1975), Maurice Goldsmith), and others to reflect the pioneering work of J.D. Bernal and its offshoots. However, the term "science of science" did not gain favor even though the Society for the Social Study of Science (4S) was formed in 1975. 


\section{SLIDE 1: PAPERS CITING PRICE VERSUS PAPERS USING THE TERM} "SCIENTOMETRICS," FROM 1956-2006.

Papers citing Price vs. Papers using the term "scientometrics"

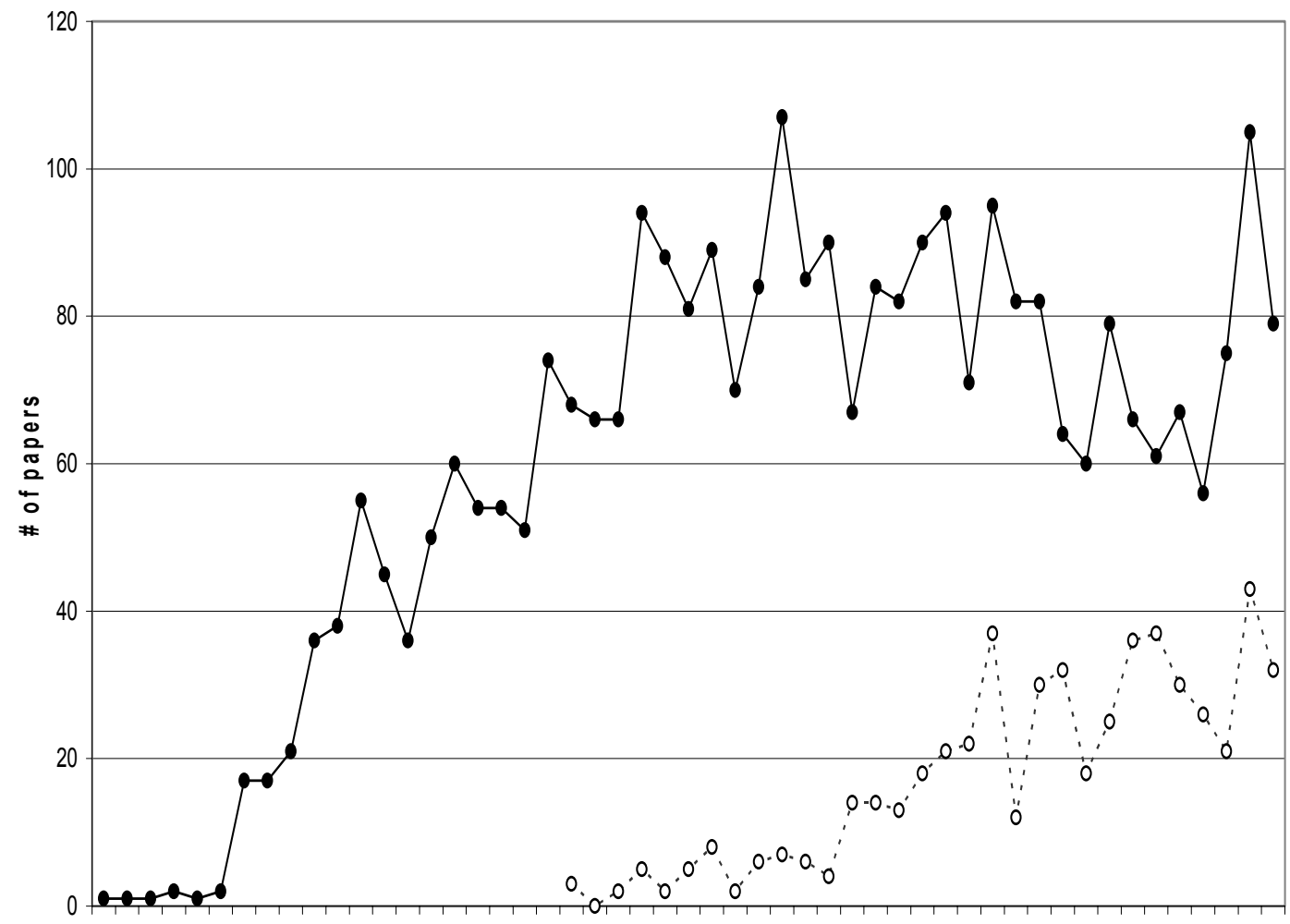

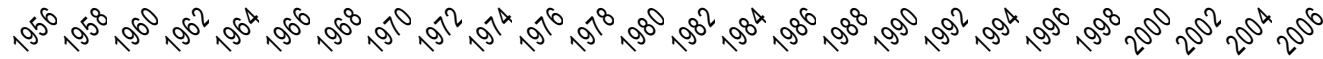

Year

\# \# of Citing Papers $\cdots 0$ - * \# papers using term "Scientometrics"

Using citations to the work of Price as one indicator of the growth of this field here is the year-by-year graph of citations to Derek's work based on using the histogram feature of HistCite or Web of Science (WoS). 
SLIDE 2: HISTORIOGRAPH OF 33 MOST-CITED WORKS IN THE COLLECTION OF PAPERS CITING PRICE FROM 1956-2006.
Historiograph of 33 papers most cited in the collection of papers citing Price, 1956-2006.

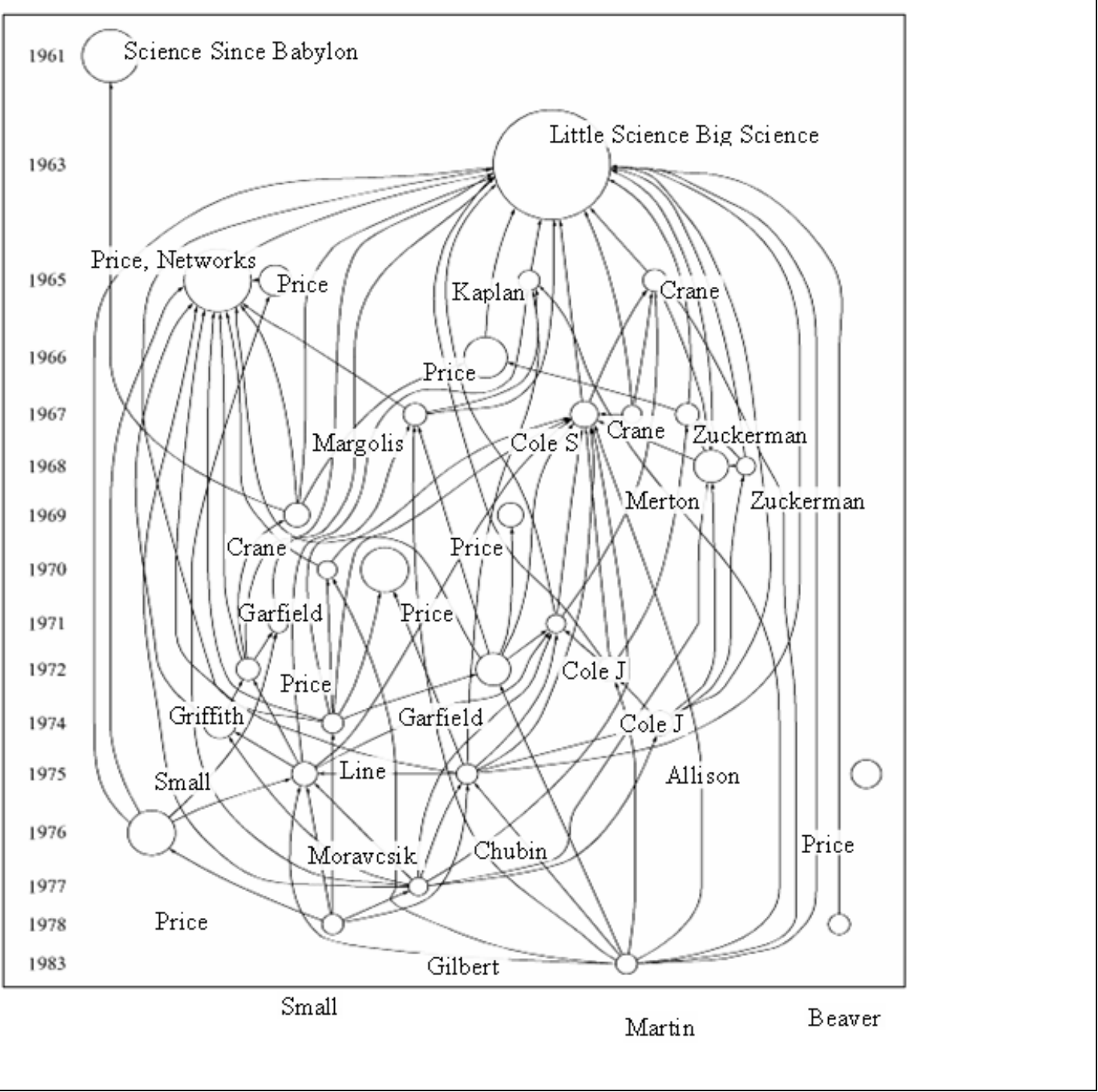

In contrast to the visible growth in citations to Price's work, an analysis of papers published in WOS containing the term scientometric(s) does not reveal the growth of the topic because the general term is displaced by more specific terminology as the field evolved.

To continue this brief discussion of the work of Derek Price, the following historiograph displays the linkages between the 35 most-cited works of the HistCite collection. Each of these papers was cited at least 107 times.

\section{SLIDES 3 AND 4: TIME LINE FOR HISTORY OF SCIENTOMETRICS}

The chronological listing of the 200 most-cited works, based on over 102,000 cited references in the collection of 3083 citing papers provides a fairly accurate historical timeline of the field (See slides 3 and 4).. 
TIME LINE FOR THE HISTORY OF SCIENTOMETRICS Author, year, reference

1 COLE FJ, 1917, SCI PROGR, V11, P578

2 LOTKA AJ, 1926, J WASHINGTON ACADEMY, V16, P317

3 GROSS PLK, 1927, SCIENCE, V66, P385

4 BRADFORD SC, 1934, ENGINEERING-LONDON, V137, P85

5 BERNAL JD, 1939, SOCIAL FUNCTION SCI

6 BUSH V, 1945, ATLANTIC MONTHLY, V176, P101

7 BRADFORD SC, 1948, DOCUMENTATION

8 VICKERY BC, 1948, J DOC, V4, P198

9 ZIPF GK, 1949, HUMAN BEHAVIOR PRINCIPLE

10 FUSSLER HH, 1949, LIBRARY Q, V19, P19

11 BARBER B, 1952, SCIENCE SOCIAL ORDER

12 LEHMAN HC, 1953, AGE ACHIEVEMENT,

13 SIMON HA, 1955, BIOMETRIKA, V42, P425 Cites

14 GARFIELD E, 1955, SCIENCE, V122, P108

15 PRICE DJD, 1956, DISCOVERY, V17, P240

16 MERTON RK, 1957, AM SOCIOL REV, V22, P635

17 MERTON RK, 1957, SOCIAL THEORY SOCIAL

18 SHOCKLEY W, 1957, P IRE, V45, P279

19 POPPER K, 1959, LOGIC SCI DISCOVERY

20 BURTON RE, 1960, AM DOC, V11, P18

21 WESTBROOK JH, 1960, SCIENCE, V132, P1229

22 KENDALL MG, 1960, OPERATIONAL RESEARCH, V11, P31

PRICE DJD, 1961, SCI SINCE BABYLON, P1

MERTON RK, 1961, P AM PHILOS SOC, V105, P470

BARBER B, 1961, SCIENCE, V134, P596

KUHN TS, 1962, STRUCTURE SCI REVOLUTION

MACHLUP F, 1962, PRODUCTION DISTRIBUT

ROGERS EM, 1962, DIFFUSION INNOVATION,

PRICE DJD, 1963, LITTLE SCIENCE BIG SCIENCE, P1

30 KESSLER MM, 1963, AM DOC, V14, P10

31 GARFIELD E, 1963, AM DOC, V14, P289

32 GARFIELD E, 1963, AM DOC, V14, P195

33 GARFIELD E, 1964, USE CITATION DATA WR,

34 GARFIELD E, 1964, SCIENCE, V144, P649

35 CLARKE BL, 1964, SCIENCE, V143, P822

36 PRICE DJD, 1964, SCIENCE, V144, P655

37 PRICE DJD, 1965, SCIENCE, V149, P510

39 PRICE DJD, 1965, TECHNOL CULT, V6, P553

40 CRANE D, 1965, AM SOCIOL REV, V30, P699

41 KAPLAN N, 1965, AM DOC, V16, P179

42 PRICE DJD, 1965, NATURE, V206, P233 


\section{TIME LINE FOR THE HISTORY OF SCIENTOMETRICS continued}

\begin{tabular}{|c|c|c|}
\hline & Author, year, reference & Cites \\
\hline 43 & PRICE DJD, 1966, AM PSYCHOL, V21, P1011 & 213 \\
\hline 44 & BAYER AE, 1966, SOCIOL EDUC, V39, P381 & $\underline{53}$ \\
\hline 45 & CARTTER AM, 1966, ASSESSMENT QUALITY G, & $\underline{42}$ \\
\hline 46 & STORER NW, 1966, SOCIAL SYSTEM SCI, & $\underline{39}$ \\
\hline 47 & SCHMOOKLER J, 1966, INVENTION EC GROWTH, & $\underline{33}$ \\
\hline 48 & BENDAVID J, 1966, AM SOCIOL REV, V31, P451 & 29 \\
\hline 49 & STORER NW, 1966, SOCIAL SYSTEM SCIENC, & $\underline{26}$ \\
\hline 50 & MAY KO, 1966, SCIENCE, V154, P1672 & 24 \\
\hline 51 & COLE S, 1967, AM SOCIOL REV, V32, P377 & 91 \\
\hline 52 & MARGOLIS J, 1967, SCIENCE, V155, P1213 & 62 \\
\hline 53 & ZUCKERMAN H, 1967, AM SOCIOL REV, V32, P391 & 61 \\
\hline 54 & CRANE D, 1967, AM SOCIOL, V2, P195 & 44 \\
\hline 55 & LEIMKUHLER FF, 1967, J DOC, V23, P197 & $\underline{40}$ \\
\hline 56 & PRICE DJD, 1967, SCI TECHNOL, V70, P84 & 33 \\
\hline 57 & MERTON RK, 1968, SCIENCE, V159, P56 & 128 \\
\hline 58 & ZIMAN J, 1968, PUBLIC KNOWLEDGE SOC & $\underline{68}$ \\
\hline 59 & ZUCKERMAN H, 1968, AM J SOCIOL, V74, P276 & 47 \\
\hline 60 & BROOKES BC, 1968, J DOC, V24, P247 & $\underline{40}$ \\
\hline 61 & MULLINS NC, 1968, AM SOCIOL REV, V33, P786 & $\underline{38}$ \\
\hline 62 & MERTON RK, 1968, SOCIAL THEORY SOCIAL & $\underline{37}$ \\
\hline 63 & COLE S, 1968, AM SOCIOL REV, V33, P397 & $\underline{32}$ \\
\hline 64 & WATSON JD, 1968, DOUBLE HELIX, & $\underline{24}$ \\
\hline 65 & CRANE D, 1969, AM SOCIOL REV, V34, P335 & 73 \\
\hline 66 & PRICE DJD, 1969, P ISRAEL ACAD SCI HU, V4, P98 & 69 \\
\hline 67 & PRITCHARD A, 1969, J DOC, V25, P348 & $\underline{47}$ \\
\hline 68 & FAIRTHORNE RA, 1969, J DOC, V25, P319 & $\underline{46}$ \\
\hline 69 & BROOKES BC, 1969, NATURE, V224, P953 & $\underline{40}$ \\
\hline 70 & MACRAE D, 1969, AM SOCIOL REV, V34, P631 & 34 \\
\hline 71 & PRICE DJD, 1969, FACTORS TRANSFER TEC, V1, P91 & 30 \\
\hline
\end{tabular}

Starting with F. J. Cole in 1917, AJ Lotka in 1926, Gross \& Gross in 1927, Samuel Bradford in 1934, and then Bernal in 1939. Vannevar Bush's classic, "As we may think" appeared in 1945 at the end of World War II (Bush, 1945). A decade later, we find the work of Herb Simon in 1955, and in the same year, the paper by yours truly. Then in 1956 Derek's paper on "the exponential growth in science," appears in 1956 (Price,1956). His first paper on quantitative studies appeared in 1951 but had very little impact! (Price, 1951)

I won't continue to recite all the names that are recalled in this exercise but I believe this list of works cited 30 or more times in the Price HistCite collection demonstrates the simple notion that bibliographic history is recapitulated rather well by the collective bibliographic memory of the scholars who have contributed to the literature, both at the macro and micro level of analysis. 
SLIDE 5: HISTCITE OF PAPERS CITING PRICE'S WORK IN

SCIENTOMETRICS

Here is the first page of the HistCite collection of 3063 papers that cited Price's work in Scientometrics.

Publications Related to the Field of scientometrics by DJD Price and the

Papers Citing Them

Historiographs Glossary HistCite Guide About

Grand Totals: LCS 12276, GCS

33574

List of All Records

Collection span: 1956 - 2006

Records: 3063, Authors: 2928, Journals: 869, Cited References: 102333, Words: 4624 Yearly output | Document Type | Language | Institution | Institution with Subdivision | Country

Page 1 of 31: [ $\left.\begin{array}{llllllllllllllll}1 & 2 & 3 & 4 & 5 & 6 & 7 & 8 & 9 & 10\end{array}\right] 11 \quad 21 \quad 31$

\begin{tabular}{|l|l|c|c|c|c|}
\hline$\#$ & LCR & NCR & Date / Author / Journal & LCS & GCS \\
\hline 1 & 0 & 1 & \multicolumn{1}{|c|}{1956} & 28 \\
\hline
\end{tabular}

1957

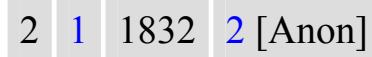

$0 \quad 0$

82ND CRITICAL BIBLIOGRAPHY OF THE HISTORY OF SCIENCE AND ITS CULTURAL INFLUENCES (TO 1 JANUARY 1957)

ISIS. $1957 ; 48$ (152): 189-268

1958

\begin{tabular}{ll|l|l}
3 & 1 & 5 & 3 \\
JOHNSON EA
\end{tabular}

THE CRISIS IN SCIENCE AND TECHNOLOGY AND ITS EFFECT ON MILITARY DEVELOPMENT

OPERATIONS RESEARCH. 1958; 6 (1): 11-34

1959
$4 \quad 1$
94 PETTERSSON M
$0 \quad 3$
MAIN STAGES OF SOCIAL EVOLUTION IN MAN
NATURE. 1959; 184 (4684): 481-482
\begin{tabular}{ll|l|l}
5 & 1 & 72 & 5 VLEDUTS GE, NALIMOV VV, STIAZHKIN NI
\end{tabular}
58
SCIENTIFIC AND TECHNICAL INFORMATION, PROBLEM OF CYBERNETICS
USPEKHI FIZICHESKIKH NAUK. 1959; 69 (1): 13-56 
SLIDE 6: BERNAL HISTCITE: Publications by Bernal and the papers citing him. (http://garfield.library.upenn.edu/histcomp/bernal-jd_citing-03/index-tl.html) I plan to present a more detailed analysis of Bernal's work at the forthcoming celebration of his 100th birthday in Ireland in September. Here is a preliminary look at the HistCite record for the 8648 papers that cited his work.

Publications by John Desmond Bernal and the Papers citing Bernal.
Historiographs
Glossary HistCite Guide About Grand Totals: LCS 32913, GCS 300877

Collection span: 1924 - 2007

List of All Records

Records: 8648, Authors: 12001, Journals: 1740, Cited References: 295645, Words: 11676 Yearly output | Document Type | Language | Institution | Institution with Subdivision | Country

Page 1 of 87: [ $\left.\begin{array}{llllllllll}1 & 2 & 3 & 4 & 5 & 6 & 7 & 8 & 9 & 10\end{array}\right] \begin{array}{lllllllll}11 & 21 & 31 & 41 & 51 & 61 & 71 & 81\end{array}$

\# LCR NCR

Date / Author / Journal

1924
163

163

The structure of graphite

PROCEEDINGS OF THE ROYAL SOCIETY OF LONDON SERIES ACONTAINING PAPERS OF A MATHEMATICAL AND PHYSICAL CHARACTER. 1924 DEC; 106 (740): 749-773

1926
99

99

On the interpretation of X-rays, single crystal, rotation photographs PROCEEDINGS OF THE ROYAL SOCIETY OF LONDON SERIES ACONTAINING PAPERS OF A MATHEMATICAL AND PHYSICAL CHARACTER. 1926 NOV; 113 (763): 117-160

3 Gibbs RE

The polymorphism of silicon dioxide and the structure of tridymite PROCEEDINGS OF THE ROYAL SOCIETY OF LONDON SERIES ACONTAINING PAPERS OF A MATHEMATICAL AND PHYSICAL CHARACTER. 1926 DEC; 113 (764): 351-368
LCS GCS

\section{7}

0

The crystal structure of potassium di-hydrogen-phosphate AMERICAN JOURNAL OF SCIENCE. 1927; 14 (82): 269-287

75 Jaeger FM, van Melle FA

0 7

Investigations into the constitution of artificial ultramarines II On ultramarine-blue with high silica-content and on silver silversodiumselenium-and silberselenium-ultramarines

PROCEEDINGS OF THE KONINKLIJKE AKADEMIE VAN WETENSCHAPPEN TE AMSTERDAM. 1927; 30 (1/5): 479-498

6 Morse JK

Atomic lattices and atomic dimensions

PNAS 1927; 13: 227-232 


\section{SLIDE 7: BERNAL'S SOCIAL FUNCTION OF SCIENCE HISTCITES}

However, a more detailed look at the impact of his book Social Function of Science is reflected in the more than 300 citing papers shown in the HistCite collection.

The Social Function of Science by Historiographs $\quad$ Glossary HistCite Guide $\underline{\text { About }}$ JD Bernal (1939, 1967) and the citing papers

Grand Totals: LCS 450, GCS

Collection span: 1939 - 2007

\section{List of All Records}

18 June 2007

Records: 367, Authors: 352, Journals: 213, Cited References: 16377, Words: 1053 $\underline{\text { Yearly output }}|\underline{\text { Document Type }}| \underline{\text { Language }}|\underline{\text { Institution }}| \underline{\text { Institution with Subdivision } \mid} \mid \underline{\text { Country }}$ Page 1 of 4: [ $1 \underline{2} \underline{3} \underline{4}]$
$\begin{array}{llll}1 & 1 & 4 & 1\end{array}$ [Anon]
Journals or micro-films?
LANCET. 1939; 1: 765-766
$\begin{array}{lllll}2 & 0 & 0 & 2 & \text { BERNAL JD }\end{array}$
The Social Function of Science
SOCIAL FUNCTION SCI. 1939;
$\begin{array}{llll}3 & 1 & 3 & 3 \text { [Anon] }\end{array}$
$0 \quad 0$
Science and society.
BRITISH MEDICAL JOURNAL. 1939 JUL-DEC; 2: 286-287

\section{4}

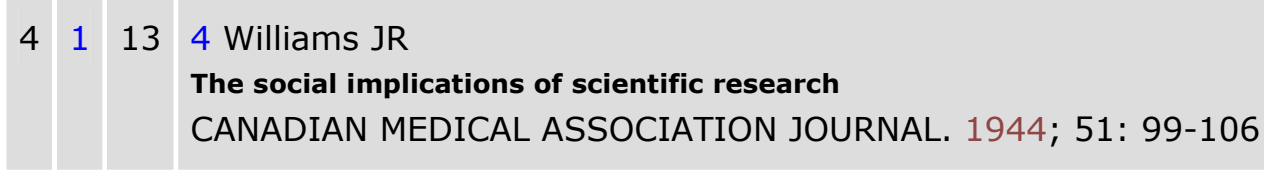

$\begin{array}{llll}5 & 1 & 18 & 5 \text { Dudley S }\end{array}$

$0 \quad 0$

Naval experience in relation to a National Health Service

LANCET. 1944; 2: 134-137

$\begin{array}{lllll}6 & 1 & 10 & 6 \text { Teich N }\end{array}$

Influence of Newton's work on scientific thought

NATURE. 1944 JAN-JUN; 153: 42-45

\section{6}

71157 BARD P, ADOLPH EF, DOW P, BOYD TE, COMROE JH

$0 \quad 0$

PHYSIOLOGY IN NORTH-AMERICA, 1945 - SURVEY BY A COMMITTEE OF THE AMERICAN-PHYSIOLOGICAL-SOCIETY

FEDERATION PROCEEDINGS. 1946; 5 (3): 407-436

$\begin{array}{llll}8 & 1 & 3 & 8 \text { [Anon] }\end{array}$

RATIONALIZATION OF THE LITERATURE OF SCIENTIFIC RESEARCH

NATURE. 1946; 157 (3997): 745-748

1947

$\begin{array}{llll}9 & 1 & 2 & 9 \\ & \text { DINGLE H }\end{array}$ 


\section{References}

1. Bensman, SJ \& Kraft, DH. (In Press.) Happy $75^{\text {th }}$ Birthday,Tibor Braun, Scientometrics.

2. Bush, V. (1945). As we may think it. Atlantic Monthly, 176:101.

3. Merton RK \& Garfield E, (1986) Foreword to Little science, Big science.. and beyond, New York: Columbia University Press, 301 pgs.

4. Nalimov VV and Mul'chenko ZM. (1969). Naukometriya. Izuchenie nauki kak informatsionnogo protsessa (Scientometrics. Study of science as an information process.) Moscow: Nauka, 192 pgs. (Available in English on microfilm: Measurement of science. Study of the development of science as an information process.

Washington, DC: Foreign Technology Division, U.S. Air Force Systems Command, 13 October 1971. 196pgs.). Retrieved March 23, 2007 from::

http://www.garfield.library.upenn.edu/nalimov/nalimovmeasurementofscience/book.pdf

5. Pritchard A. (1969). Statistical bibliography or bibliometrics? Journal of Documentation, 25, 348-349

6. Price, DJD. (1951) "Quantitative measures of the development of science," Archives Internationales d'Histoire des Sciences 14:85-93.

7. Price DJD. (1956). The exponential curve of science. Discovery 17(1):240-243.

8. Price DJD. (1963). Little Science, Big Science. New York: Columbia University Press.

9. Price Derek J. deSolla, (1965). Networks of Scientific Papers: The pattern of bibliographic references indicates the nature of the scientific research front, Science, 149(3683):510-515.

10. Price DJD. (1976). Science since Babylon. New Haven: Yale University Press.

11. Price DJD. (1975). Science since Babylon. New Haven, CT: Yale University Press.

12. Price, DJD. (1980). Foreword to Essays of an Information Scientist, Volume 3. Philadelphia: ISI Press, pgs. V-ix. http://www.garfield.library.upenn.edu/essays/v3 forewordy1977-78.pdf

13. Price DJD. (1983). This week's Citation Classic, Current Contents No. 29, pg. 18. Retrieved March 23, 2007 from: http://garfield.library.upenn.edu/classics1983/A1983QX23200001.pdf

14. Garfield, E. (1955). Citation Indexes for Science: A New Dimension in Documentation through Association of Ideas. Science 122(3159):108-11. Retrieved March 23, 2007 from:

http://www.garfield.library.upenn.edu/papers/science_v122v3159p108y1955.html

15. Garfield, E. (1964). Science Citation Index -- A New Dimension in Indexing. Science, 144(3619):649-54.

16. Tukey JW. (1962). Keeping Research in Contact with Literature - Citation Indexes and beyond. IEEE Transactions on Engineering Writing and Speech. EWS5(2):78.

17. Dedijer S. (1962). Measuring Growth of Science, Science. 138(3542):781. 